\title{
THE IMPACT OF LOCALIZATION AND BARN TYPE ON INSOLATION OF SIDEWALL STALLS DURING SUMMER
}

\author{
Sabina Angrecka ${ }^{1}$, Piotr Herbut ${ }^{1}$, Grzegorz Nawalany ${ }^{1}$, Paweł Sokołowski ${ }^{1}$ \\ 1 Department of Rural Building, University of Agriculture, al. Mickiewicza 24-28, 30-059 Krakow, Poland, e-mail: \\ s.angrecka@ur.krakow.pl
}

Received: 2017.03.15

Accepted: 2017.06.04

Published: 2017.07.01

\begin{abstract}
In the light of climate changes related to global warming forecasted by scientists, preventive measures against negative impact of solar radiation on dairy cattle welfare become vital. Apart from sprinklers and fans, different forms of shading, like native trees, extension of eaves or shade screens are increasingly often mentioned. The aim of the present studies was to determine the effect of barn type and orientation on the penetration of solar radiation into sidewall stalls during summer. A non-stationary analysis was performed for 3 types of curtain-sided freestall barns most commonly used in Poland, in which a model analysis of insolation was performed taking into account geographical location of Poland, azimuth and sun angles. The obtained results allowed us to identify optimal orientation of barns and to suggest the simplest technical measures to protect sidewall stalls from solar heat gain deleterious to cows. The model analysis of stall shading demonstrated that extension of barn eaves to $1 \mathrm{~m}$ on the southern side reduced the insolation of stalls over even up to $90 \%$ of their area.
\end{abstract}

Keywords: barn, orientation, sidewall stalls, insolation, shade, welfare.

\section{INTRODUCTION}

Freestall system is currently the most popular solution in rearing of dairy cattle in Europe. Since cows spend their whole productive life in the barn, farmers should provide them with appropriate microclimatic conditions [Herbut et al. 2015]. The greatest risk of worsening of thermal conditions is observed in summer, when ventilation is insufficient to cope with high ambient temperature accompanied by high relative humidity [Herbut et al. 2013, Nawalany and Sokołowski, 2015]. Such conditions can cause discomfort or even heat stress in cows if they have to endure them for longer periods, which results in reduction of milk production efficiency [West 2003; Stadnik and Atasever, 2015].

Since cows lie down for 8 - 16 hours per day, ensuring an optimal and undisturbed lying time is essential for their health, preventing also hoof diseases and lameness [De Palo et al. 2006; Tucker et al. 2009; Radoń et al. 2014]. The choice of the stall by the cow, comfort of lying, standing up and lying down depends on the type of stall dividers, and quality and temperature of bedding, among other things [Camiloti et al. 2012; Kaczor et al. 2011].

On development of the hygrothermal conditions in barns have impact, besides air parameters, also insolation [Herbut and Angrecka 2013]. It affects especially sidewall stalls. Bedding temperature in sidewall stalls depends mostly on stall orientation towards cardinal points and on incident solar radiation intensity [Angrecka and Herbut 2016]. It can be reduced by using different technical solutions and natural shading of the barn. Apart from low-pressure sprinklers and fans, shading provided by native trees, extension of eaves and shade screens is increasingly frequently used. Tree and bush belts and extension of eaves belong to permanent solutions in contrast to shade screens or cloths which can be mounted temporarily.

The distribution of solar radiation in Poland is very non-uniform both over time and space. Almost $80 \%$ of the total annual insolation is received in the 6-month spring-summer period with the estimated maximum of 16 hours of sunshine 
in summer. Solar radiation density in Poland on a horizontal surface ranges from 950 to 1250 $\mathrm{kWh} / \mathrm{m}^{2}$ annually [Zochowska et al. 2012].

Considering the annual pattern of solar radiation and dominating westerly winds, freestall barns are recommended to be situated so that their longitudinal axis is north-south oriented with possible several degree deviation [Herbut et al. 2013]. Such orientation of the building can also be significant for shading of stalls during summer when cows are exposed to hot weather and are at risk of heat stress.

The aim of the study was to determine the effect of barn orientation on the reach of sunlight into sidewall stalls during summer. The studies were performed in three types of curtain-sided freestall barns most often used in Poland.

\section{MATERIALS AND METHODS}

Meteorological data for the model studies of barns insolation were obtained from a meteorological monitoring station located in the dairy farm in Kobylany near Krakow during the period from June to September 2014. Outdoor temperature and relative humidity, and intensity of solar radiation were measured. Air temperature and relative humidity were measured in 6-minute intervals using integrated sensors LB-710 (LABEL) with the temperature and relative humidity measurement range of $-40^{\circ} \mathrm{C}$ do $+85^{\circ} \mathrm{C}$ and $0 \%$ do $99.9 \%$, respectively. The measurements were exact to $0.1{ }^{\circ} \mathrm{C}$ and $0.1 \%$, respectively. Solar radiation intensity was recorded with the use of pyranometer LP PYRA03 AC M12 in the range of $0-2000 \mathrm{~W} / \mathrm{m}^{2}$.

Real temperature values of bedding surface in sidewall stalls $(120 \times 260 \mathrm{~cm})$ were measured in the freestall barn in Kobylany using a thermal imaging camera FLIR i7 with detector resolution of 140x140 (19 600) pixels, measurement range of $-20^{\circ} \mathrm{C}$ to $+250^{\circ} \mathrm{C}$, sensitivity (NETD) of $0.1^{\circ} \mathrm{C}$ and accuracy of $+/-2^{\circ} \mathrm{C}$. Thermograms were recorded every 10 minutes.

Daily values of azimuth and angle of incidence of direct sunlight in the study period were adopted according to geographic coordinates of

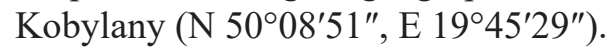

The analysis was performed for sidewall stalls $(120 \times 250 \mathrm{~cm})$ in 3 types of barns most often used in Poland (Fig. 1) differing in width, structural type (A - Fermbet, B - novel-type barns, C - Fermstal) and height of the curtain sidewalls. All stalls under analysis were situated at open longitudinal outside walls (Fig. 1). The analysis of stall orientation towards the cardinal points was based additionally on 3 most frequently used variants of barn longitudinal axis orientation: 1 - north-south, 2 - east-west, 3 - 30\% deviation from north-south (Fig. 2). The studies were conducted also to determine whether sidewall stalls can be protected from excessive heating by extension of eaves from $50 \mathrm{~cm}$ (most commonly used solution) to $100 \mathrm{~cm}$.

\section{RESULTS AND DISCUSSION}

Characteristic values of air temperature and relative humidity and solar radiation intensity during the study period in summer 2014 are presented in Table 1. The highest intensity of solar radiation was noted in August and the lowest in September (Fig. 3).

The analysis of intensities of solar radiation throughout individual study days demonstrated the highest intensity from 9:00 to 15:00. In this period, temperature of bedding in sidewall stalls reached the highest values $\left(>35^{\circ} \mathrm{C}\right)$, and cows reluctantly used those available stalls. For this reason, these hours were selected for further analysis.

Sun-exposed areas of stalls were determined using two dimensional models based on projections and cross sections of barns taking into account the month, time of the day, azimuth and sun angle. This analysis was performed for variants of barns under study and their orientation (Fig. 4) and was applied to areas of sidewall stalls.

Temperature measurements of bedding surface showed that it slightly increased with air temperature but it crucially depended on insolation. When stalls were sunlit, the temperature of bedding surface increased with solar radiation intensity, especially after 11:00. When solar radiation intensity reached the highest values (above 800 $\mathrm{W} \cdot \mathrm{m}^{-2}$ ), which were observed between 11:00 to 14:00, the temperature of bedding surface soared even to $58^{\circ} \mathrm{C}$. Compared with the normal body temperature range for a cow of $38-39^{\circ} \mathrm{C}$ and considering necessity of their cooling down during hot weather, elimination or reduction of insolation of stalls surfaces is crucial for improvement of cow comfort during resting. This is the reason why analyzed whether reduction of insolation can be achieved by extension of eaves in the barn.

During the longest days of the year (June 1528), the highest sun angles are observed, therefore, the reduction of stall insolation was the greatest 


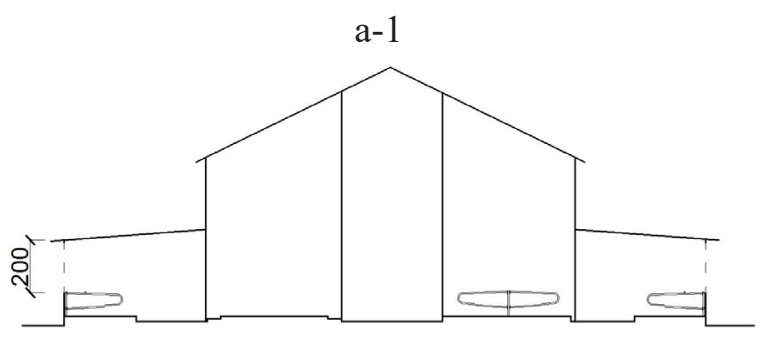

b-1

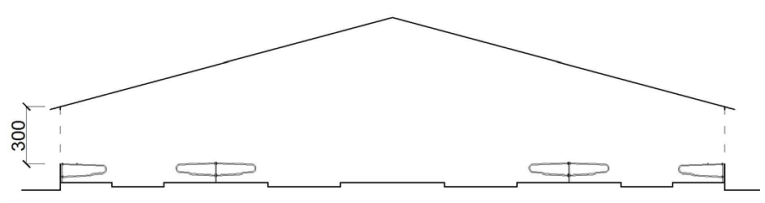

c-1

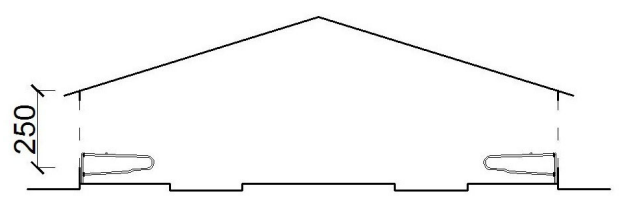

a-2

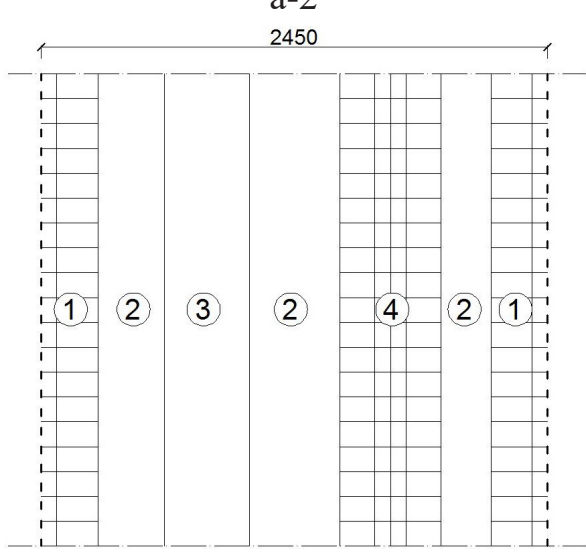

b-2

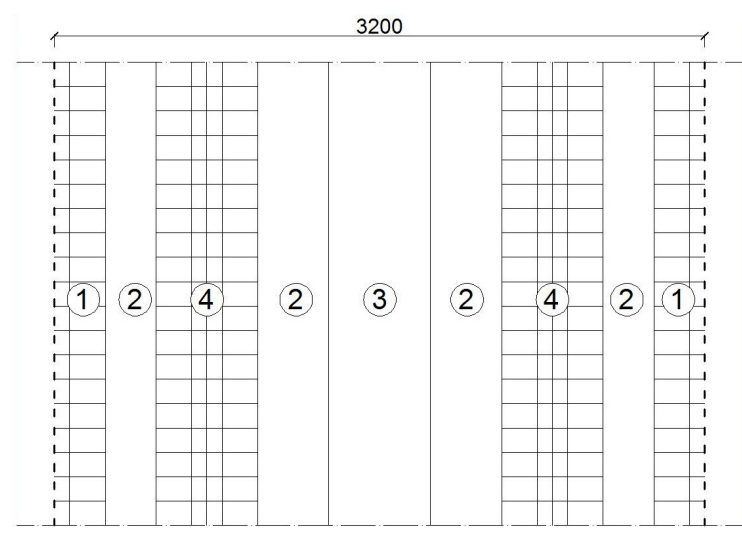

$\mathrm{c}-2$

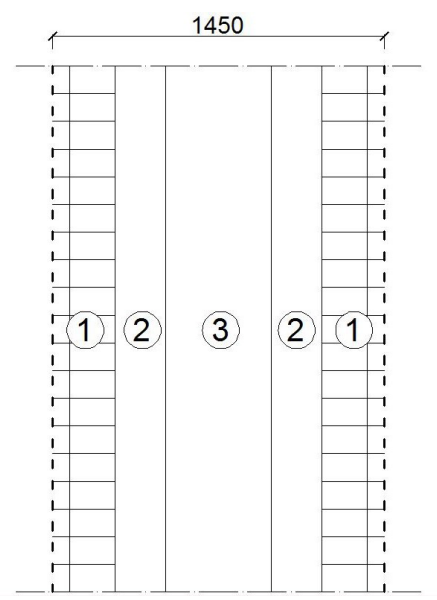

Figure 1. Characteristics of barns under analysis: $\mathrm{A}-$ Fermbet; $\mathrm{B}$ - novel type barns with the most common functional layout; C - Fermstal; 1 - sidewall stalls, 2 - manure alley, 3 - feed alley, 4 - double stalls
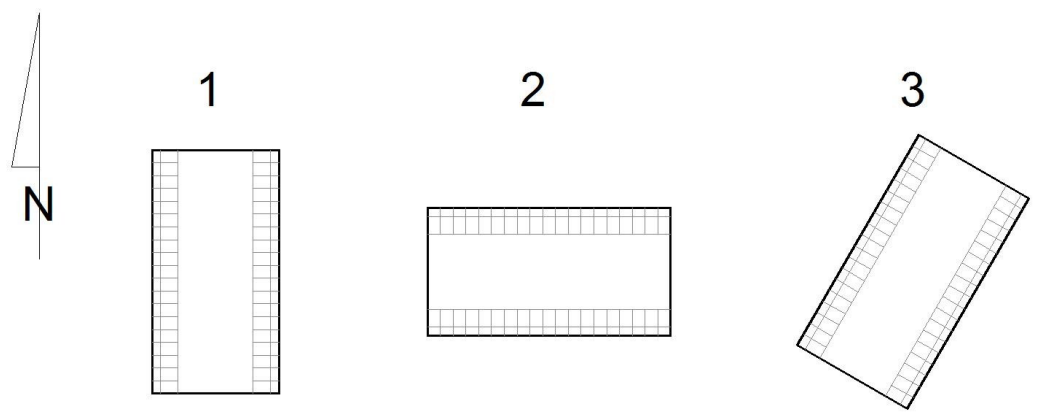

Figure 2. Variants of barn orientation: 1. north-south, 2. east-west, 3. 30\% deviation from north-south 
Table 1. Characteristic monthly average values of air temperature, relative humidity and solar radiation intensity in the study period.

\begin{tabular}{|c|c|c|c|c|}
\hline Parameter & June & July & August & September \\
\hline Air temperature, ${ }^{\circ} \mathrm{C}$ & 16.1 & 20.2 & 20.8 & 15.1 \\
\hline Relative air humidity, \% & 72.9 & 77.4 & 73.2 & 84.4 \\
\hline Solar radiation, $\mathrm{W} / \mathrm{m}^{2}$ & 403.2 & 399.8 & 410.5 & 314.9 \\
\hline
\end{tabular}

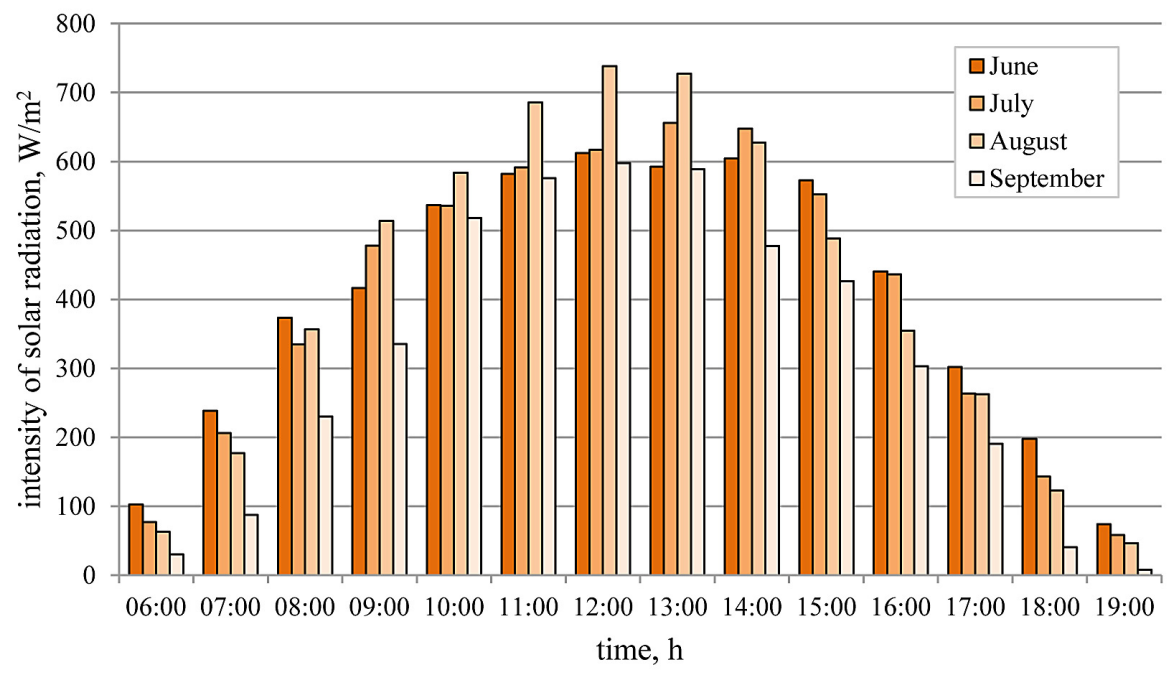

Figure 3. Monthly average hourly solar radiation intensities in the study period

a)

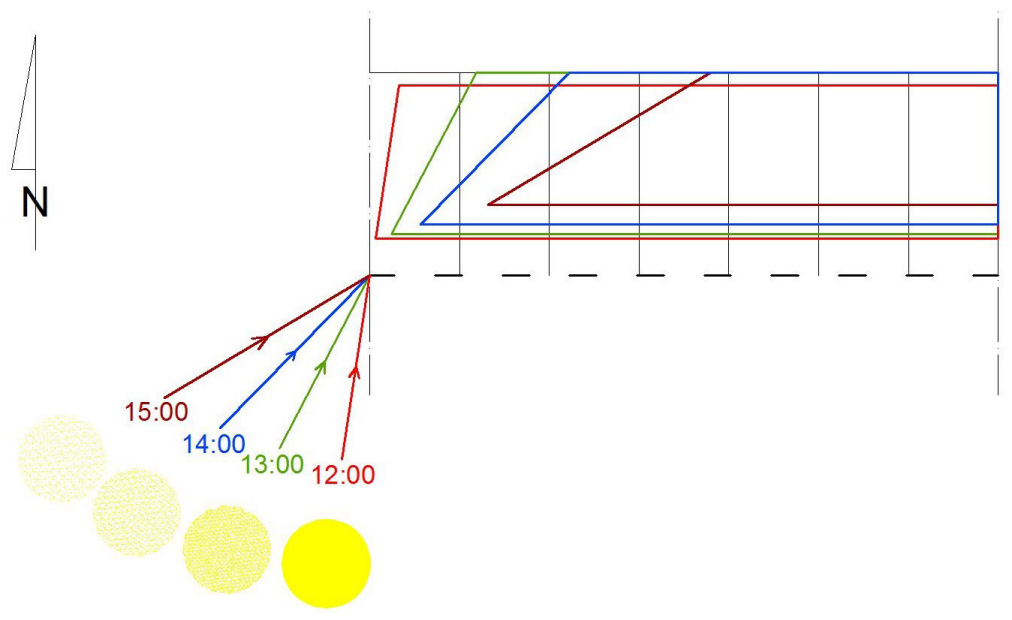

b)

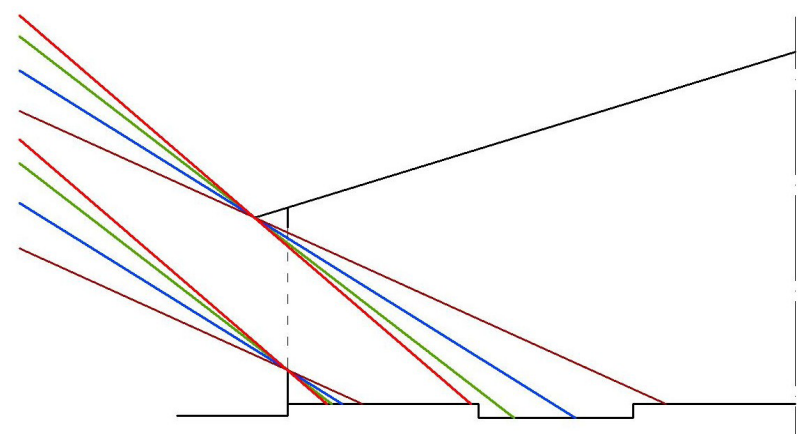

Figure 4. Examples of models of insolation parts of stalls; $a$ - projection, $b$ - cross-section 
in this period (Table 2). In barn A, independently of the orientation, extension of eaves completely eliminated insolation of stalls. In the period from 11:00 to $13: 00$ insolation was reduced by $87.4 \%$. In the case of variant 3 , stalls were not sunlit at 13:00 independently of the length of eaves. Extension of eaves in building B caused the greatest reduction of insolation in the period from 11:00 to $12: 00$ (by $61.9 \%$ on the average). Noteworthy, from 15:00 the sunlit area of all stalls was equal independently of the size of eaves . Like in buildings $\mathrm{A}$ and $\mathrm{B}$, in building $\mathrm{C}$, the largest reduction of insolation was observed from 11:00 to 13:00.

Table 3 presents the analysis performed for a mid-summer period (July 26 to August 9). In building $\mathrm{A}$, the greatest reduction was observed at 11:00 and was greater in the morning hours than around noon. It was characteristic of this building type that no reduction was noted after 14:00. No reduction was also observed at 9:00 and after 15:00 in building B. The obtained maximum reduction of insolation approached $50 \%$ at around noon.

In the period under analysis, the most beneficial reduction of insolation was obtained for building C. Insolation of stalls decreased independently of the time of the day with the maximum reduction in the period from 11:00 to 12:00. If building of any type was in orientation 3 , the stalls were not sunlit at 13:00 independently of eaves variant.
In the late summer (September 10-23) sun angles are decreased which is reflected by reduced insolation (Table 4). Type B building can be excluded from detailed analysis because independently of the orientation and eaves length the sunlit area of stalls was the same at every hour.

Compared with previous periods, in September the situation in building A was atypical. Namely, in the morning hours, sun-exposed area of stalls increased for orientation variants 1 and 3 . For variants 1 and 2, the greatest reduction was seen at 12:00 but the reduction was slight. In building $B$ the reduction was transient and at 12:00 sunlit area remained unchanged. Stalls insolation in building $\mathrm{C}$ showed a maximum reduction by ca. $30 \%$ during the noon hours. As well in the morning as in the afternoon after 14:00 insolation did not change.

Milk production efficiency in dairy cows is affected by barn microclimate, thus, cows should be provided with comfortable environment by maintaining optimal levels of air temperature and relative humidity [Angrecka and Herbut 2015]. Climate change forecasts, mostly global warming and increased solar radiation compel farmers to apply technical solutions to ensure the welfare of cattle. Studies of Schutz et al. [2009] demonstrated that cows on pasture used the shade, especially when solar radiation was most intense. According to Brown-Brandl et al. [2005] shading can reduce heat loads in cows by $30 \%$.

Table 2. Percent reduction of the insolation area of sidewall stalls after extension of eaves to $100 \mathrm{~cm}$ in buildings A, B and C considering variants 1, 2 and 3 of barn orientation in the period of June 15-28, 2014

\begin{tabular}{|c|c|c|c|c|c|c|c|c|c|}
\hline \multirow{2}{*}{ Hour } & \multicolumn{3}{|c|}{ A } & \multicolumn{3}{|c|}{ B } & \multicolumn{2}{c|}{ C } \\
\cline { 2 - 10 } & 1 & 2 & 3 & 1 & 2 & 3 & 1 & 2 & 3 \\
\hline $09: 00$ & 42.5 & 41.2 & 57.7 & 31.0 & 29.4 & 31.4 & 49.5 & 40.9 & 42.6 \\
\hline $10: 00$ & 64.5 & 64.5 & 64.9 & 45.3 & 45.3 & 45.8 & 60.3 & 60.3 & 60.7 \\
\hline $11: 00$ & 93.3 & 93.5 & 93.5 & 59.7 & 60.9 & 60.7 & 82.4 & 82.9 & 82.8 \\
\hline $12: 00$ & 100.0 & 100.0 & 100.0 & 61.3 & 64.9 & 63.7 & 87.9 & 88.9 & 88.5 \\
\hline $13: 00$ & 78.2 & 78.3 & 0.0 & 51.4 & 51.8 & 44.4 & 69.3 & 69.5 & 65.7 \\
\hline $14: 00$ & 51.4 & 51.6 & 51.6 & 37.3 & 36.3 & 36.0 & 48.6 & 47.9 & 47.7 \\
\hline $15: 00$ & 34.1 & 30.0 & 33.3 & 0.0 & 0.0 & 0.0 & 34.5 & 30.9 & 34.4 \\
\hline
\end{tabular}

Table 3. Percent reduction of the insolation area of sidewall stalls after extension of eaves to $100 \mathrm{~cm}$ in buildings A, B and C considering variants 1, 2 and 3 of barn orientation in the period of September 10-23, 2014

\begin{tabular}{|c|c|c|c|c|c|c|c|c|c|}
\hline \multirow{2}{*}{ Hour } & \multicolumn{3}{|c|}{ A } & \multicolumn{3}{|c|}{ B } & \multicolumn{2}{c|}{ C } \\
\cline { 2 - 10 } & 1 & 2 & 3 & 1 & 2 & 3 & 1 & 2 & 3 \\
\hline $09: 00$ & 33.5 & 32.3 & 33.8 & 0.0 & 0.0 & 0.0 & 34.7 & 33.4 & 35.2 \\
\hline $10: 00$ & 47.5 & 47.6 & 48.0 & 35.3 & 35.4 & 36.0 & 46.5 & 46.6 & 47.0 \\
\hline $11: 00$ & 62.0 & 63.1 & 62.9 & 42.9 & 44.8 & 44.5 & 58.1 & 59.4 & 59.2 \\
\hline $12: 00$ & 20.0 & 32.3 & 26.4 & 35.9 & 47.6 & 46.1 & 57.1 & 63.3 & 62.3 \\
\hline $13: 00$ & 12.4 & 13.0 & 0.0 & 40.0 & 40.9 & 0.0 & 53.4 & 54.1 & 0.0 \\
\hline $14: 00$ & 0.0 & 0.0 & 0.0 & 26.7 & 26.2 & 25.0 & 40.9 & 40.5 & 39.3 \\
\hline $15: 00$ & 0.0 & 0.0 & 0.0 & 0.0 & 0.0 & 0.0 & 30.3 & 27.8 & 29.3 \\
\hline
\end{tabular}


Table 3. Percent reduction of the insolation area of sidewall stalls after extension of eaves to $100 \mathrm{~cm}$ in buildings A, B and C considering variants 1, 2 and 3 of barn orientation in the period of July 26 - August 9, 2014

\begin{tabular}{|c|c|c|c|c|c|c|c|c|c|}
\hline \multirow{2}{*}{ Hour } & \multicolumn{3}{|c|}{ A } & \multicolumn{3}{|c|}{ B } & \multicolumn{2}{c|}{ C } \\
\cline { 2 - 10 } & 1 & 2 & 3 & 1 & 2 & 3 & 1 & 2 \\
\hline $09: 00$ & -4.5 & 0.0 & -4.6 & 0.0 & 0.0 & 0.0 & 0.0 & 0.0 \\
\hline $10: 00$ & -2.8 & 0.0 & -2.9 & 0.0 & 0.0 & 0.0 & 18.3 & 19.3 & 19.3 \\
\hline $11: 00$ & 16.9 & 24.3 & 21.3 & 0.0 & 0.0 & 0.0 & 23.9 & 31.2 & 30.2 \\
\hline $12: 00$ & 20.0 & 29.7 & 0.0 & 0.0 & 0.0 & 0.0 & 20.2 & 31.4 & 28.6 \\
\hline $13: 00$ & 12.3 & 13.0 & 0.0 & 0.0 & 0.0 & 0.0 & 20.8 & 22.2 & 0.0 \\
\hline $14: 00$ & 8.3 & 0.0 & 0.0 & 0.0 & 0.0 & 0.0 & 0.0 & 0.0 & 0.0 \\
\hline $15: 00$ & 0.0 & 0.0 & 0.0 & 0.0 & 0.0 & 0.0 & 0.0 & 0.0 & 0.0 \\
\hline
\end{tabular}

The present analysis of 3 types of barns demonstrated that building $\mathrm{C}$ with the curtain sidewall height of $3 \mathrm{~m}$ was the most beneficial solution. The model analysis showed that extension of eaves in the barn of this type resulted in reduction of insolation throughout the day. Buildings of this type are characterized by a relatively low height which makes it easier to reduce insolation, however, low efficiency of gravity ventilation, not analyzed in the present study, may be a problem.

Building $\mathrm{A}$ is an advantageous solution but only when sun angles are high, i.e. from June to the end of July. The closer to the end of summer the lower efficiency of eaves extension in reducing the solar heat gain by sidewall stall surface.

The building representing the newest design used in recently constructed large barns proved to be less efficient in reducing the insolation. In June and at the beginning of July, a maximum reduction of $65 \%$ was achieved but it faded later on to disappear completely in September. For this reason, it may be recommended to apply other technical or floral solutions in buildings of this type.

On the other hand, analysis of barn orientation, apart from reduction of insolation, required also examination of the time when sunlight hit the stalls from different sides of the building. The reduction values presented in Tables $2-4$ could indicate that variant 2 is the best solution. However, when the long axis is west-east oriented, stalls on the south side would be sun-exposed from early morning hours till at least 16:00. It would create the risk of excessive solar heat gain by stall surface and would adversely affect the comfort of cows in this part of the building.

Hence, variants 1 and 3 of barn orientation are more beneficial despite that the reduction did not reach the highest values in this case. For variant 1 , only stalls situated on the eastern side were exposed to sun till 11:00 while from 13:00 west stalls were affected. At noon mostly endwall and partly west stalls were exposed to solar radiation. For variant 3, from July insolation was completely eliminated at 13:00. Throughout the summer, south-eastern side of the building was exposed even till 12:00 and north-western side was sunlit from 14:00.

Sunlight penetration inside the barn and especially heating of stall surface should be analyzed considering several aspects. On the one hand, sunlight hitting the stall surface dries it out, which is beneficial and was confirmed by the time cows prefer to spend lying and by comfort of cows during resting. As shown by studies reported by Fregonesi et al. [2007], the lying time after replacement of wet bedding with dry one can increase even by 5 hours. However, correct preparation of stalls for cows cannot be limited to providing them with comfortable lying. The present studies demonstrated that in summer surface of sun-exposed stalls was heated to $40^{\circ} \mathrm{C}$ and in extreme cases even to $58^{\circ} \mathrm{C}$ which was detrimental to lying cows. During hot weather cows will prefer not to lie down in stalls the surface of which is heated which will result in reduction of the undisturbed lying time.

When hot weather combined with high humidity create uncomfortable environment, which can cause heat stress in dairy cows, bedding in stalls should be helpful in absorbing excess heat and sweat thereby cooling the animal's body [De Palo et al. 2006]. It is important especially because as reported by Aguilar [2013] 20\% of the body of a lying cow remains in contact with bedding. Kaczor et al. [2011] demonstrated that temperature of the skin on the abdomen of HF cows was $35^{\circ} \mathrm{C}$. A comparison of the air and stall surface temperature with body temperature of cows $\left(38-39^{\circ} \mathrm{C}\right)$ in the study period showed that heat dissipation to the environment and thus cooling of the cows could be difficult. 


\section{CONCLUSIONS}

1. The best reduction of insolation of stalls throughout the whole day was achieved by extension of eaves in barn $\mathrm{C}$ with curtain sidewall height of $3 \mathrm{~m}$.

2. Extension of eaves in barn A was beneficial but only when sun angles were high, i.e. from June to the end of July.

3. Reduction of insolation of stalls in barn B was not very efficient because of the height of the barn and the height of curtain sidewall. Maximum reduction of $65 \%$ was obtained in June and at the beginning of July, but it gradually faded to disappear in September.

4. A north-south orientation of barns possibly with $30 \%$ deviation of longitudinal axis was found to be the best in terms of reduction of insolation.

5 . The highest reduction of insolation was obtained in the east-west oriented barn, however, due to a day-long exposure of sidewall stalls to sunlight this solution is not recommended.

6. Extension of eaves is an optimal solution in the period of June-July. Since August sun angles are so low that extension of eaves is not able to efficiently reduce insolation of stalls.

\section{Acknowledgments}

This work was financed by the Ministry of Science and Higher Education of the Republic of Poland.

\section{REFERENCES}

1. Aguilar F.R. 2013. Computational modelling to reduce impact of heat stress in lactating cows. Doctoral dissertation, The University of Arizona, AZ, USA.

2. Angrecka S., Herbut P. 2012. Prognozowanie możliwości wystąpienia stresu cieplnego u bydła mlecznego. Wiadomości Zootechniczne, 50(4), 99-105.

3. Angrecka S., Herbut P. 2015. Conditions for cold stress development in dairy cattle kept in free stall barn during severe frosts. Czech Journal of Animal Science, 60(2), 81-87.

4. Angrecka S., Herbut P. 2016. Impact of Barn Orientation on Insolation and Temperature of Stalls Surface. Annals of Animal Science, 16(3), 887-896.

5. Brown-Brandl T.M., Eigenberg R.A., Nienaber J.A., Hahn G.L. 2005. Dynamic Response Indicators of Heat Stress in Shaded and Non-shaded Feedlot Cattle, Part 1: Analyses of Indicators. Biosystems Engineering, 90(4), 451-462.
6. Camiloti T.V., Fregonesi J.A., von Keyserlingk M.A.G., Weary D.M. 2012. Effects of bedding quality on the lying behaviour of dairy calves. Journal of Dairy Science, 95, 3380-3383.

7. De Palo P., Tateo A, Zezza F., Corrente M., Centoducati P. 2006. Influence of Free-Stall Flooring on Comfort and Hygiene of Dairy Cows During Warm Climatic Conditions. Journal of Dairy Science, 89, 4583-4595.

8. Fregonesi J.A., Veira D.M., von Keyserlingk M.A.G., Weary D.M. 2007. Effects of Bedding Quality on Lying Behaviour of Dairy Cows. Journal of Dairy Science, 90, 5468-5472.

9. Herbut P., Angrecka S., Nawalany G. 2013. Influence of wind on air movement in a free stall barn during the summer period. Annals of Animal Science, 13(1), 109-119.

10. Herbut P., Angrecka S. 2013. Forecasting heat stress in dairy cattle in selected barn zones with the help of THI and THIadj indexes. Annals of Animal Science, 13(4), 837-848.

11. Herbut P., Bieda W., Angrecka S. 2015. Influence of hygrothermal conditions on milk production in a free stall barn during hot weather. Animal Science Papers and Reports, 33(1), 49-58.

12. Kaczor A., Paschma J., Olszewski A., Paraponiuk P. 2011. Wpływ rodzaju podłoża w boksach legowiskowych na komfort wypoczynku krów oraz poziom komórek somatycznych w mleku. Roczniki Naukowe Zootechniki, 38(2), 245-255.

13. Nawalany G., Sokołowski P. 2015. Characteristics of the temperature and humidity conditions in a deep-litter barn in a summer season. Infrastruktura i Ekologia Terenów Wiejskich., IV(3), 1399-1408.

14. Radoń J., Bieda W., Lendelova J., Pogran S. 2014. Computational model of heat exchange between dairy cow and bedding. Computers and Electronics in Agriculture. 107: 29-37.

15. Schutz K.E, Rogers A.R., Cox N.R., Tucker C.B. 2009. Dairy cows prefer shade that offers greater protection against solar radiation in summer: Shade use, behaviour, and body temperature. Applied Animal Behaviour Science, 116, 28-34.

16. Stádník L., Atasever S. 2015. Influence of some environmental factors on body condition score and somatic cell count in Czech Holstein cows. Indian Journal of Animal Research. 49(6), 774-777.

17. Tucker C.B., Weary D.M., von Keyserlingk M.A.G., Beauchemin K.A. 2009. Cow comfort in tie-stalls: Increased depth of shavings or straw bedding increases lying time. Journal of Dairy Science, 92, 2684-2690.

18. West J.W. 2003. Effects of Heat-Stress on Production in Dairy Cattle. Journal of Dairy Science, 86, 2131-2144.

19. Zochowska M., Kingsbury A., Kobuszynska M. 2012. Renewable Energy and Bio-fuel Situation in Poland. Global Agricultural Information Network. 